\title{
Menakar Tantangan dan Potensi Jurusan Bahasa dan Sastra Arab (BSA) IAIN Syekh Nurjati Cirebon di Era Pendidikan 4.0
}

\author{
Erfan Gazali \\ Institut Agama Islam Neger (IAIN) Syekh Nurjati Cirebon
}

erfangazali@gmail.com

\begin{abstract}
This article discusses the readiness of the Department of Arabic Literature IAIN Syeikh Nurjati Cirebon in dealing with the development of education in the era of the industrial revolution 4.0. Descriptive-analytical method was chosen as the type of research with the stages of analyzing data including: data collection, data reduction, and drawing conclusions or verification. The level of competition based on the excellence of human resources in the era of the industrial revolution 4.0 requires all countries to move quickly in enhancing their human resources, actively contributing to the generation of superior and competitive generation as part of a knowledge-based society making responsibilities that cannot be avoided by higher education institutions. the level of education has risen to become a producer of innovation as a reflection of the educational era 4.0. Exploring all the potentials of the Arabic language and literature department of IAIN Syeikh Nurjati Cirebon and the challenges that will be faced in the era of education 4.0 will be the aim of this study. Cirebon is an area with a rich history and pluralistic culture supported by the existence of the kraton along with hundreds of manuscripts has made this area a field of knowledge and research that is very potential for the development of Arabic language and literary knowledge in Indonesia.
\end{abstract}

Keywords: Education 4.0, language,Arabic literature, Cirebon

\begin{abstract}
Abstrak
Artikel ini membicarakan tentang kesiapan Jurusan Bahasa Sastra Arab IAIN Syekh Nurjati Cirebon dalam menghadapi perkembangan pendidikan di era revolusi industri 4.0. Metode deskriptif-analitis dipilih sebagai jenis penelitian dengan tahapan menganalisa data meliputi: pengumpulan data, reduksi data, dan penarikan kesimpulan atau verifikasi. Tingkat persaingan berbasis keunggulan sumberdaya manusia di era revolusi industri 4.0
\end{abstract}


menuntut semua negara bergerak cepat dalam meningkatkan sumber daya manusianya, berkontribusi aktif dalam melahirkan generasi yang unggul dan berdaya saing sebagai bagian dari masyarakat berbasis pengetahuan menjadikan tanggung jawab yang tidak bisa dihindari oleh lembaga pendidikan tinggi. level pendidikan meningkat menjadi penghasil inovasi sebagai cerminan era pendidikan 4.0. Mengeksplorasi semua potensi diri yang dimiliki oleh jurusan bahasa dan sastra Arab IAIN Syekh Nurjati Cirebon serta tantangan yang akan dihadapi di era pendikan 4.0akan menjadi tujuan kajian ini.Cirebon adalah daerah dengan kekayaan sejarah dan kebudayaan yang plural ditopang keberadaan keraton-keraton beserta ratusan manuskrip telah menjadikan daerah ini ladang pengetahuan dan penelitian yang sangat potensial bagi pengembagan keilmuan bahasa dan sastra bahasa arab di Indonesia.

Kata kunci: Pendidikan 4.0, bahasa, Sastra Arab, Cirebon

\section{Pendahuluan}

Dunia telah masuk dalam era revolusi teknologi yang secara fundamental mengubah cara hidup, bekerja dan berhubungan antara satu dengan yang lain. Dalam skala ruang lingkup dan kompleksitasnya, transformasi yang sedang terjadi mengalami pergeseran gaya hidup dari sebelumnya. Kemajuan bidang informasi komunikasi dan bioteknologi hingga teknik materialmengalami percepatan luar biasa dan membawa perubahan radikal di semua dimensi kehidupan. ${ }^{1}$ Kondisi ini telah mengantarkanmanusia memasuki era baru dalam kehidupan kemanusiaanterutama bidang manufuktur dan industri yaitu revolusi industri (RI) keempat atau disebut industri 4.0 (selanjutnya disingkat RI 4.0).

Transformasi digital manufaktur dan pemanfaatan teknologi platform ketiga menjadi identitas RI 4.0. Teknologi informasi menjadi basis dalam kehidupan manusia. Semuanya tanpa batas dengan penggunaan daya dan data komputasi tak terbatas, karena dipengaruhi oleh perkembangan Internet dan teknologi digital masif sebagai tulang punggung gerakan manusia dan mesin serta konektivitasnya. Revolusi ini akhirnya mengubah perspektif seseorang dalam menjalani kehidupan modern dan canggih. ${ }^{2}$ Klaus Schwab sebagaipendiri sekaligus ketua forum ekonomi dunia mempertegas kondisi diatas, masuknyaera RI4.0 ditandai dengan kemunculan superkomputer, robotika, kendaraan tanpa pengemudi, editing genetik dan perkembangan neuroteknologi yang

${ }^{1}$ Anastassios Pouris, "Technology Trends: A Review of Technologies and Policies," Institute for Technological Innovation, Business Enterprises at University of Pretoria (Pty) Ltd, Pretoria, no. December (2012): 61-62.

2i-scoop, "Industry 4.0: the fourth industrial revolution - guide to Industrie 4.0," www.i-scoop.eu, 2018, https://www.i-scoop.eu/industry-4-0/. 
memungkinkan manusia untuk lebih mengoptimalkan fungsi otak, ${ }^{3}$ kecerdasan buatan (Artificial intelligence),big data, nano teknologi, komputasi quantum, seluruhnya ditujukan untuk kesejahteraan manusia. ${ }^{4}$

Saatini, salah satu keharusan yang perlu dipenuhi oleh negara-negara maju terhadap masyarakatnya ini adalah upaya peningkatan sumber daya manusia yang dilengkapi dengan persyaratan pengetahuan dan keterampilan yang berbeda sesuai dengan kebutuhan masyarakat sosial dan dunia kerja di era RI 4.0. Dunia kerja yang berubah menempatkan permintaan pada produksi pengetahuan dan aplikasi pengetahuan yang lebih inovatif. Karena itu dunia pendidikan ditantang untuk mampu meningkatkan model pedagogi yang lebih kompetitif menaikkan level mereka menjadi pendidikan 4.0 (education 4.0).Pendidikan 4.0 adalah istilah umum yang digunakan oleh para ahli teori pendidikan untuk penamaan atastren pengajaran yang memberdayakan siswa untuk menghasilkan inovasi, pendidikan 4.0 disebut juga sebagai pendidikan penghasil inovasi (innovation-producing education). ${ }^{5}$ Hadirnya pendidikan 4.0 melengkapi fenomena penetrasi digital di kehidupan manusia saat ini. pendidikan 4.0 merupakan tantangan yang tidak hanya berfokus pada apa yang diajarkan tapi juga cara pengajarannya.

Karakteristik pendidikan 1.0 cenderung bersifat pedagogik (teacher-directed instruction), Komunikasi dilakukan satu arah dari guru ke murid. Murid diasumsikan hanya perlu mengetahui apa yang diajarkan oleh guru. Guru yang memiliki keputusan apa yang penting bagi muridnya tanpa memerhatikan ketertarikan atau kebutuhan murid, dan pencapaian murid diukur melalui nilai. Pendidikan 2.0 bercirikan andragogi yang berfokus pada pendekatan Konstruktivisme di dalam kegiatan belajar dan mengajar dengan pembelajaran yang difasilitasi oleh guru. Sumber daya internet telah menjadi bagian dari kegiatan belajar level ini. Kegiatan belajar dapat dilakukan di dalam ruangan atau secara virtual. Adapun pendidikan 3.0 bercirikan pendidikan Heutagogi (selfdirected/determined learning) dengan dasar pandangan bahwa pendidikan dapat disesuaikan dan bebas dipilih sesuai dengan kebutuhan pembelajar. Peranpendidik menjadi seorang pendamping atau pelatih dan tidak menggurui lagi. ${ }^{\circ}$ Dalam Pendidikan 4.0 masih bericirikan Heutagogy tetapi diskusi ukuran kelas sudah menjadi tidak relevan. Karena lokasi pembelajaran tidak lagi ditentukan pada ukuran bangunan fisik karena mahasiswa dapat belajar dari

${ }^{3}$ Klaus Schwab, The Fourth Industrial Revolution (Geneva, Switzerland: World Economic Forum, 2016). hlm. 11-12

${ }^{4}$ Raymond R Tjandrawinata, "Industri 4.0: Revolusi Industri Abad Ini Dan Pengaruhnya Pada Bidang Kesehatan Dan Bioteknologi," Dexa Laboratories of Biomolecular Sciences (DLBS) 29, no. February (2016): 1-12, https://doi.org/10.5281/zenodo.49404.

${ }^{5}$ Arthur M Harkins, "Leapfrog Principles and Practices: Core Components of Education 3.0 and 4.0," Future Research Quality 24, no. 1 (2008): 19-31.

'Rahdian Saepuloh, "Education 3.0," padepokanmargosari.com, 2016, https://padepokanmargosari.com/2016/03/23/education-3-

$0 /$ ?iframe $=$ true\&theme_preview $=$ true. 
mana saja, dan kepada siapa saja, mereka dapat mengakses para ahli di mana saja di dunia ini.

Kemenristek Dikti selaku lembaga tinggi negara yang menaungi perguruan tinggi di Indonesia pada akhirnya melakukan kebijakan menuju pendidikan tinggi 4.0. sehingga posisi perguruan tinggi sebagai lembaga pencetak sumber daya manusia yang unggul diharapkan lebih dapat berkontribusi pada upaya peningkatan daya saing bangsa. Tidak terkecuali Jurusan Bahasa dan Sastra Arab IAIN Syekh Nurjati Cirebon selaku unit kerja dilembagapendidikan tinggi untuk ikut menjadi motor inovatif disrutifdi era RI 4.0 ini.

Apabila ditinjau dari usia berdirinya maka jurusan BSA terkategori pendatang baru dalam dunia pendidikan tinggi di Indonesia.Tahun 2018 menjadi tahun kedua beroperasinya lembaga ini, Keputusan Dirjen Pendis Kementerian Agama Nomor 5196 tahun 2016 tentang izin operasional Jurusan BSA IAIN Syekh Nurjati menjadi bukti legal dalammenjalankan mandat pendidikan tinggi di Indonesia khususnya kawasan Ciayumajakuning (Cirebon, Indramayu, Majalengka dan Kuningan). Kehadiran Jurusan BSA melengkapi 20 jurusan yang telah ada yang tersebar di tiga Fakutas, Fakultas Ilmu Terbiyah dan Keguruan (FITK), Fakultas Adab,Usuluddin dan Dakwah (FUAD) dan Fakultas Syariah dan Ekonomi Islam.

Sebagai jurusan baru ditingkat pendidikan tinggi di Indonesia, Jurusan BSA memiliki banyak ruang yang cukup luas dalam menentukan orientasi pendidikan dan paradigma belajar yang akan menjadi kompas penentu dalam mewujudkan capaian kapabilitas para lulusannya. Tulisan sederhana ini diharapkan dapat membuka ruang diskusi yang produktif dalam upaya membangun lanskap akademik di jurusan BSA IAIN Syekh Nurjati Cirebon.

Tulisan ini merupakan kajian kepustakaan (libraryresearch), sumber data yang digunakan dalam tulisan berasal dari telaah dokumentatif, terkaitpotensi pendidikan kebahasaan dan sastra arab di wilayah Cirebon dan revolusiindustri 4.0. Pengolahan data dalamnya menggunakan metodedeskriptif-analitis, yaitu model penelitian yang berupaya mendeskripsikan, mencatat,menganalisa dan menginterpretasikan kondisi-kondisi yang ditemukan baik dalam telaah dokumen dan realitas lapangan sehingga diharapkanmemberi gambaran potensi dan tantangan yang dimiliki oleh jurusan bahasa dan sastra arab di era revolusi industri 4.0

\section{Hasil Kajian dan Pembahasan}

Teknologi komunikasi dan informasi terbarukan telah menciptakan kondisi-kondisi yang disebut masyarakat berbasis pengetahuan(knowledge based society)atau masyarakat berpengetahuan (knowledge society).Masyarakat berpengetahuan dibangun di atas dasar kecerdasan manusia, inovasi teknis dan kekuatan informasi dan pengetahuan. Tipikal masyarakat berpengetahuan 
diyakini memiliki potensi untuk mencapai dampak positif yang lebih langgeng terhadap pendidikan, kemakmuran ekonomi, inklusi sosial dan perlindungan lingkungan, serta membawa umat manusia maju ke era baru perdamaian dan pembangunan berkelanjutan. ${ }^{7}$ Inilah era globalisasi, era persaingan berbasis keunggulan sumberdaya manusia.Hal ini menjadi tantangan global yang dihadapi oleh dunia pendidikan termasuk Perguruan Tinggi di Indonesia.

\section{Tantangan Pendidikan Era Global (Globalization of Education)}

\section{Fenomena Inovasi Disrupsi (disruptive innovation)}

Revolusi Industri 4.0 telah menciptakan fenomena dalam dunia bisnis yang disebut sebagaiinovasi disrupsi (disruptive innovation),yaitu sebuah inovasi yang menciptakan sebuah tren baru dan jejaring industri baru, yang akhirnya 'mengganggu' pasar dan nilai yang terlebih dahulu sudah ada, lantas menggantikan 'pemain lama'tersebut untuk menjadi pemimpin pasar kemudian membuat aliansi di dalamnya. ${ }^{8}$

Pergerakan dunia industri atau persaingan kerja tidak lagi bersifat linear. Perubahannya terjadi sangat cepat, mengacak-acak pola tatanan lama dan menciptakan tatanan baru secara fundamental. Disrupsi telah menginisiasi lahirnya model bisnis baru dengan strategi lebih inovatif dan disruptif. Cakupan serta jangkauan perubahannya sangat luas mulai dari dunia perbankan, transportasi, bisnis, sosial masyarakat, hingga pendidikan.

Dalam dunia pendidikan inovasi disrupsi akan mendorong terjadinya digitalisasi sistem pendidikan, praktik pembelajaran akan berubah total. Ruang kelas mengalami evolusi dengan pola pembelajaran digital yang memberikan pengalaman pembelajaran yang lebih beragam bersifat partisipatif, kreatif, dan menyeluruh.Keberadaan teknologi informasi telah menghapus sekat-sekat geografis yang memicu munculnya cara-cara baru untuk menghasilkan ragam inovasi-inovasi terbarukan. perkembangan dalam teknologi digital dengan artificial intelligence (AI) yang mengubah data menjadi informasi, membuat orang dengan mudah dan murah memerolehnya.

Waras Kamdi, dalam tulisannya pendidikan tinggi 4.0 yang dimuat kompas $(3 / 3 / 2018)$ mengritik perguruan tinggi yang 'telat mikir' dalam mengantisipasi dan merespon RI. 4.0, rendah agilitas dan kedodoran menghadapi pesatnya perubahan. Kemajuan infrastruktur, terutama gedung dan fasilitas kelas, memang berubah. Akan tetapi, kultur belajar dan pelajaran tidak beranjak dari tradisi puluhan tahun bahkan abad silam. Sistem pendidikan tinggi tidak cukup memberi ruang terjadinya konvergensi ilmu pengetahuan dan teknologi. Sistem

${ }^{7}$ UNESCO, "Towards Knowledge Societies for Peace and Sustainable Development" (Paris, 2013), hlm. 18

${ }^{8}$ Joseph L. Bower dan Clayton M Christensen, "Disruptive Technologies: Catching the Wave," Harvad Business Review, 1995, hlm. 48 
pembelajaran tak cukup memberi lorong-lorong terjadinya pengalaman belajar transdisiplin. Selain itu, pertumbuhan program-program studi serta bidangbidang keilmuan terhambat oleh sekat-sekat antar disiplin ilmu9.

Perubahan ini berpengaruh pada tata kerja perguruan tinggi sebagai salah satu sumber produsen inovasi, termasuk perubahan dalam tata cara belajar dan mengajar didalamnya. Dalam menghadapi berbagai tantangan dan perubahan tersebut, jurusan BSA sebagai bagian dari unit perguruan tinggi diharapkan berkontribusi dalam pengembangan ilmu kebahasaaaraban dan menjadikan inovasi sebagai keniscayaan dalam proses pembelajaran sehingga mampu menjalankan berbagai perannya, yaitu pendidikan dan pengajaran, pengembangan, serta diseminasi untuk menjadi khazanah ilmu bagi masyarakat dan membantu masyarakat memanfaatkan karya pengembannya.

\section{Generasi Z (Digital Native) dan Bonus Demografi Penduduk Indonesia}

Menurut laporan Badan Pusat Statistik Indonesia pada tahun 2015 jumlah penduduk muda Indonesia yang berusia 15-34 tahun berjumlah 83,56 juta orang (33\%) dari total penduduk Indonesia sekitar 255 juta orang. sedangkan penduduk berusia 0-14 tahun sebanyak 70,8 juta orang atau $28 \% .{ }^{10}$ Generasi muda ini dikenal sebagai generasi Milenial (dikenal juga sebagai generasi $\mathrm{Y}$ ) dan generasi pasca milenial atau dikenal sebagai generasi generasi Z (Gen-Z). Generasi millennial adalah kelompok demografis yang lahir antara tahun 1981 dan 1994 atau mereka yang berusia 24-36 tahun di tahun 2018, sementara Gen$\mathrm{Z}$ adalah generasi yang lahir antara 1995 dan 2010 yang berusia 8-23 tahun di 2018.11Bonus demografi untuk bangsa Indonesia akan mulai dinikmati dan mencapai puncaknya di tahun 2040.

Dunia pendidikmasa sekarang dituntut untuk lebih mampu harus memahami tipikalsiswa milenial mereka dan bagaimana cara mereka belajar, maka pendidik akan lebih berhasil dalam menciptakan lingkungan yang berpusat pada pembelajaran. Peran pendidik telah berkembang dari tidak hanya menjadi ahli konten, tetapi juga menjadi pengembang pembelajaran bersifat sepanjang hayat. Kemampuan generasi ini juga menambah pergeseran dalam strategi pengajaran para guru. Peyampaian konten kreatif harus diintegrasikan untuk menjaga keterlibatan siswa baik di dalam maupun di luar kelas. ${ }^{12}$

Waras Kamdi, "Pendidikan Tinggi 4.0,” Kompas, 3 Maret 2018.

${ }^{10}$ Subdirektorat Demografi, "Penduduk Indonesia: Hasil Survei Penduduk Antar Sensus 2015," Katalog BPS 2101014 (Jakarta, 2015), hlm, 1-4

${ }^{11}$ Corey Seemiller dan Meghan Grace, Generation Z Goes to College (New York: JosseyBass, 2016), hlm. 6-7

${ }^{12}$ Michele Monaco dan Malissa Martin, "The Millennial student: A new generation of learners," Atbletic Training Education Journal 2, no. 2 (2007): 42-46. 
Sekolah-sekolah yang masih berpegang pada paradigma pembelajaran lama dan umumnyamengunakan metode teknologi rendah, terutama masih mendominasinya metode ceramah sebagai cara untuk menyampaikan konten dan memposisikan siswa sebagai pendengar pasif telah terbukti kurang berhasil dalam membawa para siswanya kehasil pembelajaran dan pengembangan yang sukses, ${ }^{13}$ Generasi Net (nama lain dari Gen-Z) memiliki sedikit kesabaran dengan metode pendidikan yang dianggap oleh mereka ketinggalan zaman, seperti ceramah satu arah dengan membuat mereka pendengar pasif sehingga mereka tidak memiliki kesempatan untuk mengaktulisasi diri, menawarkan ide, atau berdapat. ${ }^{14}$

\section{Potensi dan KekuatanJurusan BSAIAIN Syekh Nurjati Cirebon}

\section{Bahasa dan kesusastraan Arab dalam khazanah keindonesiaan}

Menurut Russel Jones ada 2750 kata dalam bahasa Indonesia yang merupakan serapan dari leksikon bahasa Arab. ${ }^{15}$ Tetapi menurut Nicolas Van Dam lebih dari 3000 kata bahasa Indonesia merupakan derivasi dari kata-kata Arab,ini karena kompilasi Jones tidak menyertakan kata-kata turunan yang begitu melimpah dalam bahasa Indonesia. Misalnya, syair, yang menghasilkan bersyair, menyairkan, penyair, kepenyairan, syairi dan sebagainya. ${ }^{16}$

Tidak hanya aspek kosakata, sejarah literasi nusantara mencatat bahwa aksara Arab (bijäiyah) pernah menjadi aksara yang digunakan dalam tulis menulis di Nusantara sampai menjelang perang dunia I hingga pada akhirnya pemerintah Belanda mengganti aksara Arab menjadi Aksara Latin dan berupaya secara sistematis melemahkan pengaruh bahasa Arab di Nusantara. ${ }^{17}$ Buktinya adalah adanya pengunaan huruf-huruf Arab pengon dalam naskah-naskah nusantara.

Dalam kacamata kesusastraan Indonesia, kesusastraan Arab berkontribusi memberi warna terhadap kemunculan sastra di Indonesia salah satunya sastra sufistik.Menurut para sejarawan, sastra Melayu dianggap sebagai cikal bakal bentuk kesusasteraan Nusantara lainnya, seperti pantun, gurindam, taliban, karmina, dan lain.Adalah Syekh Hamzah Fansuri diyakini seorang pelopor sastra

\footnotetext{
13Josipa Roksa dan Richard Arum, Academically Adrift: Limited Learning on College Campuses (Chicago: University of Chicago Press, 2011), hlm.130

${ }^{14}$ Bob Pletka, Educating the Net Generation: How to Engage Students in the 21st Century, 2 ed. (Santa Monica, CA: Santa Monica Press, 2007), hlm.34

${ }^{15}$ Russell Jones, "Loan-words in contemporary Indonesian," in Towards a Description of Contemporary Indonesian: Preliminary Studies part II . NUS A: Studies in Indonesian and Other Languages in Indonesia vol. 19, ed. oleh Jhon WM Verhaar (Jakarta: Badan Penyelenggara Nusa - Universitas Atmajaya, 1984), 1-38.

${ }^{16}$ Nikolaos van Dam, “Arabic Language in Contemporary Indonesian," bahasakita.com, 2009, http://bahasakita.com/arabic-language-in-contemporary-indonesian/.

${ }^{17}$ Tajudin Nur, "Sumbangan Bahasa Arab Terhadap Bahasa Indonesia Dalam Perspektif Pengembangan Bahasa dan Budaya," Humaniora 26, no. 2 (2014): 235-43.
} 
sufi jenis puisi dan dianggap sebagai perintis kesusasteraan Indonesia lama, beliau seorang ahli tasawuf berasal dari pulau Sumatera dan diperkirakan hidup pada medio abad ke-16 perintis tarekat al-Qadiriyah dan aliran tasawuf wabdat alwujud di Indonesia.

Syeikh Hamzah Fansyuri sering mengutip pernyataan dan syair-syair Ibnu 'Arabi serta 'Iraqi untuk menopang pemikiran kesufiannya. Di bagian lain lagi, khususnya di dalam puisi-puisinya, Syeikh banyak memeroleh ilham dari karya 'Attar Manthiq al-Thair (musyawarah Burung). ${ }^{18}$ Menurut Ali Hasyimi di dalam 32 ikat-ikatan syair syekh Hamzah Fansyuri saja terdapat kurang lebih 700 kata ambilan dari bahasa Arab, yang bukan saja memperkaya pembendaharaan kata bahasa Melayu, tetapi dengan demikian juga mengintegrasikan konsep-konsep Islam di dalam berbagai bidang kehidupan ke dalam sistem bahasa dan budaya Melayu. ${ }^{19}$

\section{Khazanah kearifan lokal dan kecerdasan lokal (Genius Wisdom) Cirebon}

Kemajuan era informasi dengan segala capaiannya berpengaruh pada terjadinya pergeseran nilai hidup yang dianut oleh umat manusia.Nilai-nilai unik dan khas pada setiap capaian budaya manusia semakin tergerus oleh nilai-nilai baru yang datang dari luar dengan nuansa keseragaman.Nilai budaya lokal yang menjadi kekuatan pendorong dan pengendali krisis eksistensi manusia atas keterasingannya dengan kehidupan harus dilakukan upaya transformasi menuju arah baru yang sesuai dengan semangat lokalitas dan globalitas (globalisasi).Pembentukan dan pewarisan suatu nilai dari satu generasi ke generasi merupakan suatu proses transformasi (perubahan Rupa berupa bentuk, sifat, fungsi, dan sebagainya).Dalam proses transformasi itulah pendidikan berfungsi mentransformasikan nilai-nilai yang diakui sebagai suatu yang unggul. 20

Dalamtransformasinilai dalam hubungan sosial kemanusiaan setidaknya mengalami proses-proses imitasi, identifikasi dan sosialisasi.Ketiga proses transformasi ini berkaitan erat dengan bagaimana mentransformasikan nilai-nilai yang terkandung dalam sebuah budaya kepada generasi selanjutnya. Menurut Aris Shoimin ada dua cara transformasi nilai yaitu 'peran serta' dan bimbingan.Cara 'peran serta' antara lain melalui keikutsertaan dalam kegiatankegiatan sehari-hari. Sedangkan bentuk bimbingan dapat berupa pengenalan dan

\footnotetext{
${ }^{18}$ Ali Hasymy, Sejarah Masuk dan Berkembangnya Islam di Indonesia (Bandung: Alma'arif, 1993), hlm. 12-21

${ }^{19}$ Hasymy, hlm. 16

${ }^{20}$ Fauzi, "Peran Pendidikan Dalam Transformasi Nilai Budaya Lokal Di Era Millenial," Insania 23, no. 1 (2018): 51-65.
} 
pendampingan. Adapun proses transformasi nilai melalui tahapan tiga tahap yakni: tahap pengetahuan (knowing), pelaksanaan (acting), dan kebiasaan (babit).21

Dalam konteks Jurusan bahasa dan sasra Arab IAIN Syekh Nurjatisebagai lembaga yang berada dalam wilayah Cirebon ditutut ikut serta menjadi bagian transformasi nilai-nilai budaya lokal yang mulai terserabut dari akar kehidupan bermasyarakat dan berbangsa. Menciptakan generasi yang kompeten dalam bidang kebahasaan tetapi tetap menjadi 'agen' penjaga khazanah nilai-nilai kemanusiaan yang lahir dari budaya Cirebon.

\section{Sejarah dan Budaya Cirebon}

Kisah asal-usul kota Cirebon dapat ditemukan dalam catatan historiografi tradisional dalam bentuk manuskrip (naskah) yang ditulis pada abad ke-18 dan ke-19. Dianatara naskah yang memuat sejarah awal Cirebon adalah Cerita Purwaka Caruban Nagari, Babad Cirebon, Sejarah Kasultanan Cirebon, Babad Walangsungsang, dan naskah Carita Purwaka Caruban Nagari. Naskah Carita Purwaka Caruban Nagariditulis oleh Pangeran Aria Cirebon, Putera Sultan Kasepuhan pada tahun 1720. Dalam naskah ini disebutkan bahwa asal mula kata Cirebon adalah Sarumban, kemudian mengalami perubahan pelafalan menjadi Caruban. Kata ini mengalami proses perubahan lagi menjadi Carbon, berubah menjadi kata Cerbon, dan akhirnya menjadi kata "Cirebon. Kata Caruban mengandung makna Campuran, yang bercampur yang bukan hanya etnis, tetapi agama yang dianut masyarkatnya juga bercampur. ${ }^{22}$

Pada abad ke-15 dan 16 masehi, Cirebon adalah kesultanan Islam ternama di Jawa Barat dibawah pimpinan Syarif Hidayatullah atau yang dikenal Sunan Gunung Jati. Pada masa itu, Cirebon dikenal juga sebagai "Jalur Sutra". Adanya Pelabuhan Muara Jati yang berada di lalu lintas utama kawasan tersebut telah menjadi arena perdagangan internasional. Pelabuhan yang ramai dan jalur utama transportasi yang menghubungkannya dengan wilayah-wilayah lain menyebabkan kota tersebut tampil dengan keterbukaan dan menerima, atau paling tidak, menjadi tempat persinggahan bagi setiap budaya, gerakan, dan pemikiran yang melintasi kawasan tersebut. ${ }^{23}$

Secara geokultural, wilayah kebudayaan Cirebon membentang pada dua sisi berbeda. Sisi utara berhadapan dengan laut Jawa, orientasi kehidupan masyarakatnya berpusat pada segara; dan sisi selatan umumnya memiliki orientasi

${ }^{21}$ Aris Shoimin, Guru Berkarakter untuk Implementasi Pendidikan Karakter (Yogyakarta: Gava Media, 2014), hlm. 73

${ }^{22}$ Happy Indira Dewi, “Akulturasi Budaya Pada Perkembangan,” in Proceeding PESAT (Psikologi, Ekonomi, Sastra, Arsitektur \& Sipil), vol. 3 (Depok: Universitas Gunadarma, 2009), D55-66.

${ }^{23}$ Mahrus El-mawa, "Rekonstruksi Kejayaan Islam di Cirebon; Studi Historis pada Masa Syarif Hidayatullah (1479-1568)," Jumantara 3, no. 1 (2012): 100-127. 
ke darat. Barat dan timur dapat diposisikan sebagai wilayah geografis yang memiliki dua kecenderungan orientasi yang sama dengan utara dan selatan. Dua orientasi ini melahirkan dua basis kebudayaan berbeda: Cirebon Larang (pesisir) dan Cirebon Girang (pedalaman). Kedua wilayah kebudayaan ini telah melahirkan ragam budaya, yaitu kesenian dan fenomena sosial, juga termasuk karakter khusus dalam soal keagamaan, sosial politik, dan ekonomi. ${ }^{24}$

Dalam konteks sejarah kota Cirebon banyak kelebihan dan keunikan misalnya adanya ada tiga keraton di Cirebon yang ketiganyamemiliki kekhasan yang berbeda. (1) keraton Kasepuhan (2) Keraton Kecirebonan, dan (3) keraton Kanoman. Seiring sejalan dengan berkembangan agama Islam di tatar Sunda berkembang pula kecerdasan lokal yang melingkupi perjalanan sejarah masyarakat Cirebon hingga kini. Hadirnya karya Seni pahat kaligrafi, seni lukis kaca, kerajinan batik, kerajinan rotan, seni budaya pesisiran hingga kuliner yang beranekaragam merupakan akulturasi dari berbagai bangsa yang pernah hadir di bumi Cirebon.

\section{Manuskrip (Naskah Kuno)}

Naskah kuno dalam penjelasan UU No. 43 Tahun 2007 tentang Perpustakaan pasal 1 ayat 4 didefiniskan sebagai :

"Semua dokumen tertulis yang tidak dicetak atau tidak diperbanyak dengan cara lain, baik yang berada di dalam negeri maupun di luar negeri yang berumur sekurangkurangnya 50 (lima pulub) tabun, dan yang mempunyai nilai penting bagi kebudayaan nasional, sejarah dan ilmu pengetahuan".

Kedudukan naskah Naskah tulisan tangan (manuscript) dapat menjadi salah satu representasi dari berbagai sumber lokal yang paling otoritatif dan paling otentik dalam memberikan berbagai informasi sejarah pada masa tertentu. ${ }^{25}$

Kota Cirebon pada mulanya adalah sebuah kerajaan yang dikenal dengan nama kesultanan Cirebon. Kerajaan ini didirikan oleh Syarif Hidayatullah atau Sunan Gunung Jati, sebagai salah seorang penyebar ajaran Islam di wilayah ini. Dengan demikian, Kesultanan Cirebon adalah kerajaan Islam yang cukup kuat di wilayah Jawa bagian barat, maka tinggalan naskah-naskahnya dapat dipastikan akan banyak berhubungan dengan ajaran-ajaran Islam. Yang dimaksud dengan naskah Islam adalah naskah-naskah yang berisi ajaran-ajaran Islam, seperti naskah Al-Qur'an, Tafsir, Hadis, Fikih, Tauhid, Tasawuf, dan Sejarah.Sebaran dan jumlah naskah Islam Cirebon sangat banyak. ${ }^{26}$

${ }^{24}$ M. Alie Humaedi, “Budaya Hibrida Masyarakat Cirebon,” Jurnal Humaniora 25, no. 3 (2013): 281-95.

${ }^{25}$ Oman Faturahman, "Khazanah Naskah-Naskah Islam Nusantara," melayuonline.com, 2007, http://melayuonline.com/ind/opinion/read/103/khazanah-naskahnaskah-islam-nusantara.

${ }^{26}$ Alfan Firmanto, "Historiografi Islam Cirebon ( Kajian Manuskrip Sejarah Islam Cirebon )," Lektur Keagamaan 13, no. 1 (2015): 31-58. 
Koran Republika dalam laman digitalnya 25 Maret 2012 pernah mengangkat tema berita 'Ratusan Naskah Kuno Cirebon Memprihatinkan'Sultan Sepuh XIV Keraton Kasepuhan Cirebon, PRA Arief Natadiningrat menuturkan 'sedikitnya 150 naskah kuno yang ada di Keraton Kasepuhan kondisinya hampir rusak, sehingga harus segera dilakukan upaya pengamanan, untuk itu pibak Keraton tengah mengupayakan proses digitalisasi. Naskah-naskah tersebut bertuliskan huruf Arab pegon dan berbahasa Cirebon'. Naskah-naskah itu berbicara tentang sejarah, baik sejarah Cirebon maupun sejarah nasional, tafsir-tafsir Alquran, obat-obatan, maupun berbagai macam pengetahuan lainnya. ${ }^{27}$ Pada kesempatan berbeda PRA Arief Natadiningrat menyatakan bahwa naskah-naskah tersebut menjadi prioritasnya untuk didedah secara Bertahap, tetapi ia menyadari bahwa pihaknya mempunyai keterbatasan sumber daya manusia (SDM). Karena itu, selama ini naskah yang diyakini berharga tersebut belum tersentuh. ${ }^{28}$

Berdasarkan data yang dihimpun Thesaurus of Indonesian Islamic Manuscripts (http://tiim.ppim.or.id/) yang dikembangkan oleh Puslitbang Lektur dan kahzanah Keagamaan, MORA, Kementerian Agama, bekerja sama dengan Pusat Pengkajian Islam dan Masyarakat (PPIM) UIN Syarif Hidayatullah Jakarta, pertanggal 25 Maret 2017 setidaknya terdapat 3.143 teks yang sudah berhasil dientri, dengan berbagai jenis tema seperti hagiografi tradisional, tasawuf, tale and folklor, tafsir Alquran, hadis Nabi, teologi, serta tema ethics atau akhlak, di sekian banyak manuskrip tersebut tercatat 549 manuskrip beraksarakan Arab dan 106 naskah beraksara pegon (Jawa, Sunda dan Melayu).

Jurusan BSA sebagai lembaga pendidikan yang memiliki piranti keilmuan terkait manuskrip dituntut untuk bergerak aktif dalam upaya pelestarian (Preservasi) naskah kuna baik dengan pendekatan fisik naskah melalui konservasi dan restorasi atau pendekatan teks naskah (isi) melalui upaya digitalisasi, katalogisasi, dan riset, serta disalin (ditulis ulang), dialih aksarakan, dan diterjemahkan.

\section{Pesantren : laboratorium karakter dan bahasa}

Menurut Wiki Aswaja Ensikopedia NU dalam portalnya moslemwiki.com tercatat ada 16 pondok pesantren yang belokasi di kota Cirebon dan 352 Pesantren di kabupaten Cirebon. empat diantaranya adalah pesantren tertua di Cirebon, yaitu Ponpes Ciwaringin (1705 M), Ponpes Buntet (1785M), Ponpes Benda Kerep (1826 M) dan Ponpes Kempek (1908 M).

\footnotetext{
${ }^{27}$ Republika.co.id, "Ratusan Naskah Kuno Cirebon Memprihatinkan,” republika.co.id, 2012, http://www.republika.co.id/berita/nasional/umum/12/03/25/m1 fora-ratusan-naskahkuno-cirebon-memprihatinkan.

${ }^{28}$ JPPN.com, "Cara Sultan Keraton Kasepuhan Cirebon Merevitalisasi Aset Kerajaan," Jppn.com, 2013, https://www.jpnn.com/news/cara-sultan-keraton-kasepuhan-cirebonmerevitalisasi-aset-kerajaan.
} 
Pesantren sebagai salah satu sub sistem pendidikan nasional yang lahir daribudaya asli Indonesia, lembaga ini mempunyai karakteristik khusus dan keunggulan dalam menerapkan pendidikan karakter bagi pesertadidiknya (santri). Transformasi nilai-nilai pendidikan pesantren yang berlangsung sepanjang tahun, melalui beragam sarana (lisan, tulisan perbuatan dan kenyataan). Dalam proses pembelajarannya terdapat pengawasan yang ketat berkaitan tata nilai atau etika terutama berkaitan tentang perilaku peribadatan khusus dan norma-norma muamalat tertentu. Pendidikan dipesantren bertitik tekanpada aspek afektif dan psikomotorik bukan hanya terfokus aspek kognitif saja karennya program bimbingan dan norma belajar supaya cepat pintar dan cepat selesai boleh dikatakan hampir tidak ada disana. Karakter pesantren yang demikian itu menjadikan pesantren dapat dipandang sebagai institusi yang efektif dalam pembangunan akhlak dan karakter. ${ }^{29}$

Dalam perpektif pembelajaran bahasa, posisi pesantren dapat menjadi model percontohan laboratorium kebahasaan. Penelitian yang dilakukan oleh Ismail Suardi Wekke ${ }^{30}$ dan Bakhtiar Mahmud ${ }^{31}$ membuktikan keberhasilan pembelajaran bahasa di pesantrenberupa realisasi kemampuan bahasa yang aktif oleh siswa dan guru. Kondisi tersebut didukung oleh beberapa faktor. (1) pembelajaran menggunakan pendekatan komunikatif dalam mengaktualisasikan kurikulum dengan metode instruksi langsung; (2) peran guru memiliki posisi penting dalam merangsang proses komunikasi siswa, didukung oleh proses belajar mengajar di mana bahasa pengantar tidak menggunakan bahasa ibu; (3) sistem asrama sebagai laboratorium bahasa adalah penerapan prinsip bahasa dalam kehidupan sehari-hari secara kontekstual; dan (4), penguatan manajemen dengan menerapkan aturan bahasa asing yang harus dipatuhi oleh seluruh penghuni pondok pesantren.

Kehidupan berbahasa masyarakat pesantren dengan ragam aktivitas di dalamnya menjadi lapangan penelitian yang potensial dalam kajian kebahasaan dan memberi kontribusi keilmuan terutama dalam perspektif sosiolinguistik, psikolinguistik, terjemahan, pembelajaran bahasa bahkan korpus bahasa.

\section{Kearifan lokal (local wisdom) Cirebon}

Cirebon memiliki keragaman suku dan akulturasi dari berbagai suku bangsa, melahirkan masyarakat yang heterogen yaitu suku Cirebon. Mayoritas

\footnotetext{
${ }^{29}$ M Ali Mas'udi, "Peran Pesantren Dalam Pembentukan Karakter Bangsa," Paradigma 2, no. 1 (2015), hlm.9

${ }^{30}$ Ismail Suardi Wekke, "Arabic Language Teaching and Learning in Muslim Minority of West Papua," Jurnal Pendidikan Islam 6, no. 1 (2017): 147-68, https://doi.org/10.14421/jpi.2017.61.147-168.

${ }^{31}$ Bakhtiar Mahmud, "Teacher Solution To Solve The Problem In Implementing The Activities Used In Teaching Speaking English In Islamic Boarding School Darussalam Gontor," in The 2nd TEYLIN International Conference Proceedings, 2017, 81-88.
} 
penduduk pribumi beragama Islam, latar belakang sejarah Indonesia seperti masuknya agama Hindu-Budha pada abab ke 4. Hadirnya bangsa Asing ke Cirebon.Seperti: Belanda, China, Timur Tengah, menambah warna dan menjadi kekayaan budaya yang dimiliki masyarakat Cirebon. ${ }^{32}$

Masyarakat Cirebon merupakan komunitas masyarakat yang mewarisi nilai-nilai luhur dari tokoh agama Islam di tanah Jawa, yakni Syarif Hidayatullah (1448-1568 M) atau yang lebih dikenal dengan julukan Sunan Gunung Jati. Keberhasilannya dalam aktivitas dakwah dan sosial budaya di Cirebon telah menempatkan dirinya sebagai tokoh pemimpin (umara) sekaligus juga cendikiwan (ulama) yang mewariskan nilai-nilai luhur yang menjadi kearifan lokal komunitas masyarakat Cirebon salah satunya adalah petatah petitih, menurut Efendi petatah-petitih Sunan Gunung Jati banyak mengandung unsur nilai ketakwaan dan keyakinan, kedisiplinan, kesopanan, tatakrama, kearifan, kebijakan dan kehidupan sosial. ${ }^{33}$

Pada sisi lain masyarakat Cirebon juga memiliki banyak tradisi yang masih terjaga dan dilaksanakan hingga sekarang diantara (1) Panjang jimat, upacara adat mencuci atau membersihkan benda pusaka milik keraton, kegiatan yang dilaksanakan dalam rangka memperingati hari kelahiran Nabi Muhammad SAW yang diperingati setiap tanggal 12 Rabiul Awal atau sebut oleh masyarakat sekitar dengan bulan maulud. (2) Memitu, acara slametan. Seperti halnya masyarakat lainnya, tradisi ini dilakukan pada saat kandungan anak pertama memasuki usia tujuh bulan. (3) Nadran, upacara adat untuk mensyukuri hasil tangkapan ikan serta keselamatan saat berlayar dan terhindar dari marabahaya selama mencari mencari nafkah dilaut. (4) Tradisi sedekah bumi, (5) Syawalan gunung jati, tradisi ziarah makam gunung jati selepas perayaan idul fitri. (6) Ganti Walit,upacara adat menganti atap makam keluarga Ki Buyut Trusmi yang terbuat dari anyaman daun kelapa, upacara dilaksanakan tanggal 25 maulud. (7) Rajaban, tradisi ziarah di makam pangeran panjunan dan pangeran kejaksan yang dilaksanakan tanggal 27 Rajab.

Apabila kajian budaya begitu menekankan pada dimensi ideologi yang diaktualisasikan melalui tanda-tanda bahasa, setidaknya karya Clifford Geertz ${ }^{34}$, The Religion of Java, setidaknya telah memberikan pencerahan bagi kesadaran akademis-kritis dalam memandang persoalan budaya. Budaya (culture) bukan lagi semata-mata kumpulan ide, sistem, bahasa, organisasi sosial, seni, ataupun artefak-artefak dan diyakini kebenarannya oleh sekelompok orang atau masyarakat partikular. Lebih dari itu, Geertz telah mengabarkan betapa budaya

${ }^{32}$ Oda I.B. Hariyanto, "Destinasi Wisaya Budaya dan Religi Di Cirebon," Ecodemica 4, no. 2 (2016): 214-22.

${ }^{33}$ Khasan Effendy, Pepatah-petitih Sunan Gunung Djati Ditinjau dari Aspek Nilai dan Pendidikan (Bandung: Indra Prahasta, 1994),hlm. 13-34

${ }^{34}$ Clifford Geertz, The Religion of Java (Chicago: University of Chicago Press, 1976), hlm. $1-477$ 
pada dasarnya dipenuhi kepentingan-kepentingan partikular untuk memapankan kelompok-kelompok atau kelas-kelas partikular dalam formasi dan struktur sosial melalui simbol-simbol dan ritual yang terus dipraktikkan dan diwacanakan secara luas ke dalam realitas dan imajinasi anggota masyarakat sehingga menjadi keyakinan yang terus diyakini kebenarannya.

Oleh karena itulah kajian-kajian kebahasaan yang dimotori institusi bahasa dan sastra seperti jurusan BSA IAIN Syekh Nurjati sudah seharusnya menempatkan dimensi kritis untuk menerjemahkan atas apa yang tersimpan dalam realitas budaya masyarakat Cirebon pada khususnya dan budaya di Nusantara pada umumnya. Kajian-Kajian bahasa lebih diarahkan untuk menjawab pertanyaan mengapa sebuah bentuk dan makna dipilih dalam komunikasi dan tidak lagi berkutat hanya sebatas pertentangan antara bahasa sebagai sistem (struktur) dengan bahasa sebagai fungsi,karena keduanya saling melengkapi dan menyempurnakan untuk menemukan ideologi tersembunyi dari penutur.

Sesuatu yang amat fundamental dalam pandangan Roger Fowler ${ }^{35}$ dan Norman Fairclough ${ }^{36}$ adalah terdapatnya fungsi hubungan antara konstruksi tekstual dengan kondisi-kondisi sosial, institusional, dan ideologis dalam prosesproses produksi serta resepsinya. Struktur-struktur lingual digunakan untuk mensistematisasikan dan mentransformasikan realitas. Oleh karena itu, dimensi kesejarahan, struktur sosial, dan ideologi merupakan sumber utama pengetahuan dan hipotesis dalam kerangka kerja kritisisme linguistik

\section{Pusat PeradabanIslam Jawa Barat}

Cirebon telah menjadi pusat aktivitas penyebaran Islam di Pulau Jawa bagian barat sekaligus menjadi pusat peradaban Islam yang memiliki beberapa karakter antara lain: ${ }^{37}$

1. Pertumbuhan kehidupan kota bernafaskan Islam dengan pola-pola penyusunan masyarakat serta hirarki sosial yang kompleks.

2. Berkembangnya arsitektur baik sakral maupun profan, misalnya mesjid agung Cirebon (Sang Cipta Rasa), keraton-keraton (Kasepuhan, Kanoman, Kacerbonan, dan Kaprabonan), dan bangunan siti bingil yang mengadaptasi rancang bangun dan ornamen lokal termasuk pra-Islam.

3. Pertumbuhan seni lukis kaca dan seni pahat yang menghasilkan karya-karya kaligrafi Islam yang sangat khas Cirebon antara lain memperlihatkan hadirnya anasir antropomorfis yang tidak lazim dalam seni rupa Islam.

\footnotetext{
${ }^{35}$ Roger Fowler, Linguistic Criticism (Oxford: Oxford University Press, 1986), hlm. 6.

${ }^{36}$ Norman Fairclough, Language and Power (London: Longman Group UK Limited., 1989), hlm. 26

${ }^{37}$ Hasan Muarif Ambary, Menemukan Peradaban Jejak. Arkeologis dan Historis Islam Indonesia (Jakarta: Logos, 1998). hlm. 109-110
} 
4. Perkembangan bidang kesenian lainnya seperti tari, membatik, musik, dan berbagai seni pertunjukan tradisional bernafaskan Islam, ragam hias awan khas Cirebon, dan lain-lain.

5. Pertumbuhan penulisan naskah-naskah keagamaan dan pemikiran keagamaan yang sisa-sisanya masih tersimpan di keraton-keraton Cirebon dan tempat-tempat lain di Jawa Barat seperti Museum Prabu Geusan Ulun Sumedang dan Museum Cigugur Kuningan yang sampai sekarang belum seluruhnya dipelajari secara seksama.

6. Tumbuhnya tarekat aliran syatariyah yang kemudian melahirkan karya-karya sastra dalam bentuk serat suluk yang mengandung ajaran wujudiah atau martabat yang tujuh. Tradisi serat suluk ini kemudian amat berpengaruh pada tradisi sastra tulis serupa di Surakarta.

7. Tumbuhnya pendidikan Islam dalam bentuk pesantren di sekitar Cirebon, Indramayu, Karawang, Majalengka, dan Kuningan

\section{Jurusan BSAdan Capaian Kompetensi yang diharapkan}

\section{Multi Kompetensi (hard skill dan soft skill)}

Direktur Jenderal Pembelajaran dan Kemahasiswaan, Kemenristek Dikti RI, Intan Ahmad dalam kesempatan Rapat Kerja Nasional (Rakernas) Ristekdikti 2018 di Medan pada 17 Januari 2018 mengatakan :38

'Di Era Revolusi Industri 4.0 kita perlu mengembangkean literasi baru yaitu data, teknologi dan sumber daya manusia, kita harus bisa memanfaatkan dan mengolah data, menerapkannya kedalam teknologi dan tentunya kita harus memahami cara penggunaan teknologi tersebut. Literasi manusia menjadi penting untuk bertahan di era ini, tujuannya adalah agar manusia bisa berfungsi dengan baik dilingkungan manusia dan dapat memahami interaksi dengan sesama manusia. Oleb karena itu universitas perlu mencari metoda untuk mengembangkan kapasitas kognitif mahasiswa: higher order mental skills, berpikir kritis \& sistemik, amat penting untuk bertahan di era revolusi industri 4.0"

Dalam paradigma bahasa, konsep literasi bukan hal yang baru, literasi adalah kemampuan individu di dalam mengolah serta memahami informasi pada saat menulis ataupun membaca. walaupun demikian, kata literasi ini juga merujuk pada keterampilan bahasa yang lainnya yang meliputi pengetahuan bahasa tulis serta lisan yang sebenarnya membutuhkan serangkaian pengetahuan tentang genre, kultural dan kemampuan kognitif. Penyematan tiga kompetensi literasi pada diri lulusan Jurusan BSA IAIN Syekh Nurjati yaituLiterasi data,

${ }^{38}$ Direktorat Jenderal Pembelajaran dan Kemahasiswaan, "Era Revolusi Industri 4.0: Perlu Persiapkan Literasi Data, Teknologi dan Sumber Daya Manusia," ristekdikti.go.id, 2018, http://belmawa.ristekdikti.go.id/2018/01/17/era-revolusi-industri-4-0-perlu-persiapkan-literasidata-teknologi-dan-sumber-daya-manusia/. 
Literasi Teknologi, dan Literasi Manusiamenjadi suatu hal yang bukan mustahil dilakukan.

Literasi Data (Data Literation) adalah kemampuan untuk membaca, analisa dan menggunakan informasi dari Big Data dalam dunia digital. Sedangkan Literasi Teknologi (Technological Literation) adalah kemampuan seseorang untuk bekerja secara independen maupun bekerjasama dengan orang lain secara efektif, penuh tanggung jawab dan tepat dengan menggunakan instrumen teknologi untuk mendapat, mengelola, kemudian mengintegrasikan, mengevaluasi, membuat serta mengkomunikasikan informasi. Dan Literasi Manusia (Human Literation) adalah dalam bidang Kemanusiaan, berupa mampu berinteraksi dengan baik, tidak kaku, dapat melakukan pendekatan kemanusian dengan melaksanakan komunikasi yang baik dan berbobot, selain harus menguasai desain kreatif dan inovatif.Di sisi lain, hal yang menjadi perhatian adalah penguasaan kompetensi dan performansi berbahasa asing khususnya bahasa Arab, baik keterampilan produktif maupun reseptif sebagai kecakapan utama yang menjadi garansi bagi lulusan juruan BSA IAIN Syekh Nurjati Cirebon.

\section{Pendekatan Transdisipliner}

Masyarakat dunia sedang menghadapi tantangan global yang sangat besar seperti kerusakan alam atau semakin menipisnya sumber daya bahkan perubahan iklim, ${ }^{39}$ yang terus mengancam keberlangsungan hidup umat manusia bahkan peradaban mereka. Para ahli telah menemukan bahwa untuk menghadapi tantangan yang kompleks ini, masukan dari berbagai disiplin ilmu saja dirasa tidak terlalu cukup untuk mampu menyelesaikan sebuah permasalahan yang kompleks tersebut. ${ }^{40}$ Mereka berpendapat selain upaya interdisiplin keilmuan perlu ada upaya integrasi pengetahuan di berbagai disiplin ilmu. Diperlukan pendekatan yang mampu mengintegrasikan ragam keilmuan, maka pendekatan transdisipliner diklaim mampu melakukannya.

Transdisipliner adalah pendekatan yang mengeintegrasikan dan mentransformasi suatu bidang pengetahuan dari beragam perspektif untuk meningkatkan pemahaman terhadap masalah yang dicoba diselesaikan untuk meningkatkan keputusan pilihan dimasa mendatang, pendekatan ini bertujuan untuk membangun pandangan-pandangan yang diperlukan untuk mengeksplorasi makna baru dan sebuah sinergitas. ${ }^{41}$

${ }^{39}$ Elinor Ostrom, "A General Framework for Analyzing Sustainability of SocialEcological Systems,” Science 325, no. 5939 (2009): 419-422.

${ }^{40}$ Jana Zscheischler, Sebastian Rogga, dan Thomas Weith, "Experiences with transdisciplinary research: Sustainable land management third year status conference," Systems Research and Behavioral Science 31, no. 6 (2014): 751-56, https://doi.org/10.1002/sres.2274.

${ }^{41}$ Batmang, "Pendekatan Transdisipliner (Suatu Alternatif Pemecahan Masalah Pendidikan)," Jurnal Al-Ta'dib Vol. 9, no. 2 (2016): 44-54. 
Pendekatan ini bertujuan adanya proses belajar bersama antar disiplin keilmuan dengan tidak hanya sekedar pengetahuan dari berbagai disiplin ilmu tetapi juga memungkinkan keterlibatan 'tokoh-tokoh' non akademisi (seperti pihak eksekutif dan legislatif juga masyarakat) dalam pemecahan masalah tersebut.Karena itu diyakini mampu menciptakan pengetahuan yang berorientasi pada solusi dengan cara yang melahirkan produk hasil yang relevan melalui praktik dan ilmu pengetahuan. ${ }^{424344}$ Karena praktik belajar generasi abad 21 yang harus dilihat lebih hanya sekedar asimilasi pengetahuan baru (mencocokkan informasi baru dengan skema-skema yang sudah ada) pada diri individu, tetapi juga sebagai proses di mana pembelajar harus terintegrasi ke dalam komunitas pengetahuan. 45

Dalam kajian bahasa dan sastra,pengunaan pendekatan lintas disiplin keilmuan merupakan hal yang umum terjadi. Setidaknya pendekatan interdisipliner dalam ilmu bahasa dan kesusastraan telah melahirkan banyak disiplin keilmuan baru seperti Forensik bahasa, Filologi (bahasa dan teks), Psikolinguistik, Sosiolinguistik, etnolinguistik, Neurolinguistik, Patologi bahasa, Genolinguistik, Ekologi Bahasa dan Linguistik komputasi, antropologi sastra, sosiologi sastra. Semuanya adalah sebagian kecil dari kajian yang mengunakan pendekatan interdisipliner. Akan tetapi pertumbuhan teknologi yang memungkinkan proses pembelajaran terintegrasi dalam sistem digital akan semakin mendorong banyaknya kajian-kajian lintas disiplin ilmu yang lebih luas dan komplek.

Penggunaan pendekatan transdisiplin dilakukan untuk mengatasimasalahmasalah global yang bersifat multisektoral.Kata kunci dari pendekatantransdisiplin adalah sinergitas dan integrasi.Sinergi dapat dimaknai sebagai luaran atau hasil optimal yang diperoleh dari interaksi antar komponendalam sebuah sistem. ${ }^{46 h a l}$ yang digaris bawahi dalam pendekatan intrasdisipliner bukanlah proses linier, tetapi terjadi dalam siklus berulang dan reflektif. ${ }^{47}$

${ }^{42}$ Daniel J. Lang et al., "Transdisciplinary research in sustainability science: Practice, principles, and challenges," Sustainability Science 7, no. SUPPL. 1 (2012): 25-43, https://doi.org/10.1007/s11625-011-0149-x.

${ }^{43}$ Roland W. Scholz et al., "Transdisciplinary case studies as a means of sustainability learning: Historical framework and theory," International Journal of Sustainability in Higher Education 7, no. 3 (2006): 226-51, https://doi.org/10.1108/14676370610677829.

${ }^{44}$ Scholz et al.

${ }^{45}$ Erfan Gazali dan Hasan Saefuloh, "Kebutuhan Peserta Didik Dan Rancang Bangun Media Pembelajaran Bahasa Arab Di Madrasah Aliyah," Arabi: Journal of Arabic Studies 4, no. 1 (2019): 87-99.

${ }^{46}$ Batmang, "Pendekatan Transdisipliner (Suatu Alternatif Pemecahan Masalah Pendidikan)."'hlm. 48

${ }^{47}$ Lang et al., "Transdisciplinary research in sustainability science: Practice, principles, and challenges," hlm. 25-43 


\section{Penutup}

Pedidikan 4.0 bukan sekedar digitalisasi pendidikan karena perubahan instrumental adalah sebuah niscayaan karena revolusi teknologi akan masuk kesemua lini kehidupan manusia perubahan yang diharapkan adalah inovasi aktivitas kurikuler yang hakiki, yakni menyentuh dataran proses belajar dan pengalaman belajar mahasiswa. Paradigma belajar di jurusan BSA dituntut beradaptasidengan karakteristik mahasiswanya dari generasi milenal dan Gen-Z, pemilihan heutagogis paradigma belajar menjadi pihan terbaik dengan bersinergi mengunakan kemutakhiran media belajar yang berbasis digital. Disain kurikulum berbasis kapabilitas adalah pilihan yang mampu menyiapkan lulusan yang kompetitif.

Diakhir tulisan ini, Kajian ilmu-ilmu bahasa dengan pendekatantransdisiplineryang berintegrasi dengannilai-nilai keislaman dan kearifan lokal akan menjadi daya pembeda diantara jurusan serumpun. Selain penguatan teori-teori kebahasaan dan sastra sebagai mata kuliah inti pilihan kajian interdisipliner linguistik berikut bisa menjadi penyokong kompetensi lususan BSA IAIN Syekh Nurjati. Seperti :Forensik bahasa, Leksikologi, Filologi (bahasa dan teks), Psikolinguistik, Sosiolinguistik, Etnolinguistik, Neurolinguistik, Patologi bahasa, Genolinguistik, Ekologi Bahasa dan Linguistik komputasi. Kajian interdisipliner sastra seperti Antropologi Sastra, Sosiologi Sastra.

Saran untuk menjadi pertimbangan bagi pemangku kebijakan lembaga pendidikan khususnya program studi ataupun jurusan bahasa dan sastra Arab yaitu (1) perlu upaya analisis terukur terhadap kelebihan dan kekurangan yang dimiliki lembaga untuk mengukur capaian peluang-peluang yang lebih besar, sehingga memudahkan bagi lembaga menyiapkan para lulusan dalam kompetisi global; (2) dialektika keilmuan bidang bahasa dan kesusastraan bahasa arab dengan kebudayaan lokal melalui pendekatan trandisipliber hendaknya menjadi wacana diskursus ruang-ruang kajian akademik sehingga kontribusi dan upaya membumikan bahasa arab semakin nyata. Waullabu 'Alam bis Showab

\section{Bibliografi}

Ambary, Hasan Muarif. Menemukan Peradaban Jejak Arkeologis dan Historis Islam Indonesia. Jakarta: Logos, 1998.

Batmang. "Pendekatan Transdisipliner (Suatu Alternatif Pemecahan Masalah Pendidikan)." Jurnal Al-Ta'dib Vol. 9, no. 2 (2016): 44-54.

Bower, Joseph L., dan Clayton M Christensen. "Disruptive Technologies: Catching the Wave." Harvad Business Review, 1995.

Dam, Nikolaos van. "Arabic Language in Contemporary Indonesian." bahasakita.com, 2009. http://bahasakita.com/arabic-language-in- 
contemporary-indonesian/.

Davies, Anna, Devin Fidler, dan Marina Gorbis. Future Work Skills 2020. Palo Alto, CA: University of Phoenix Research Institute, 2011. https://doi.org/10.13140/RG.2.1.3839.4721.

Dewi, Happy Indira. "Akulturasi Budaya Pada Perkembangan.” In Proceeding PESAT (Psikologi, Ekonomi, Sastra, Arsitektur \& Sipil), 3:D55-66. Depok: Universitas Gunadarma, 2009.

Direktorat Jenderal Pembelajaran dan Kemahasiswaan. "Era Revolusi Industri 4.0: Perlu Persiapkan Literasi Data, Teknologi dan Sumber Daya Manusia." ristekdikti.go.id, 2018. http://belmawa.ristekdikti.go.id/2018/01/17/erarevolusi-industri-4-0-perlu-persiapkan-literasi-data-teknologi-dan-sumberdaya-manusia/.

Effendy, Khasan. Pepatah-petitih Sunan Gunung Djati Ditinjau dari Aspek Nilai dan Pendidikan. Bandung: Indra Prahasta, 1994.

El-mawa, Mahrus. "Rekonstruksi Kejayaan Islam di Cirebon; Studi Historis pada Masa Syarif Hidayatullah (1479-1568)." Jumantara 3, no. 1 (2012): 100-127.

Fairclough, Norman. Language and Power. London: Longman Group UK Limited., 1989.

Faturahman, Oman. "Khazanah Naskah-Naskah Islam Nusantara." melayuonline.com, 2007. http://melayuonline.com/ind/opinion/read/103/khazanah-naskahnaskah-islam-nusantara.

Fauzi. "Peran Pendidikan Dalam Transformasi Nilai Budaya Lokal Di Era Millenial.” Insania 23, no. 1 (2018): 51-65.

Firmanto, Alfan. "Historiografi Islam Cirebon ( Kajian Manuskrip Sejarah Islam Cirebon )." Lektur Keagamaan 13, no. 1 (2015): 31-58.

Fowler, Roger. Linguistic Criticism. Oxford: Oxford University Press, 1986.

Gazali, Erfan, dan Hasan Saefuloh. "Kebutuhan Peserta Didik Dan Rancang Bangun Media Pembelajaran Bahasa Arab Di Madrasah Aliyah." Arabi: Journal of Arabic Studies 4, no. 1 (2019): 87-99.

Geertz, Clifford. The Religion of Java. Chicago: University of Chicago Press, 1976.

Hariyanto, Oda I.B. "Destinasi Wisaya Budaya dan Religi Di Cirebon." Ecodemica 4, no. 2 (2016): 214-22.

Harkins, Arthur M. "Leapfrog Principles and Practices: Core Components of Education 3.0 and 4.0." Future Research Quality 24, no. 1 (2008): 19-31. 
Hasymy, Ali. Sejarah Masuk dan Berkembangnya Islam di Indonesia. Bandung: Alma'arif, 1993.

Humaedi, M. Alie. "Budaya Hibrida Masyarakat Cirebon.” Jurnal Humaniora 25, no. 3 (2013): 281-95.

i-scoop. "Industry 4.0: the fourth industrial revolution - guide to Industrie 4.0." www.i-scoop.eu, 2018. https://www.i-scoop.eu/industry-4-0/.

Jones, Russell. "Loan-words in contemporary Indonesian." In Towards a Description of Contemporary Indonesian: Preliminary Studies part II . NUSA: Studies in Indonesian and Other Languages in Indonesia vol. 19, diedit oleh Jhon WM Verhaar, 1-38. Jakarta: Badan Penyelenggara Nusa - Universitas Atmajaya, 1984.

JPPN.com. "Cara Sultan Keraton Kasepuhan Cirebon Merevitalisasi Aset Kerajaan.” Jppn.com, 2013. https://www.jpnn.com/news/cara-sultankeraton-kasepuhan-cirebon-merevitalisasi-aset-kerajaan.

Kamdi, Waras. "Pendidikan Tinggi 4.0.” Kompas. 3 Maret 2018.

Lang, Daniel J., Arnim Wiek, Matthias Bergmann, Michael Stauffacher, Pim Martens, Peter Moll, Mark Swilling, dan Christopher J. Thomas. "Transdisciplinary research in sustainability science: Practice, principles, and challenges." Sustainability Science 7, no. SUPPL. 1 (2012): 25-43. https://doi.org/10.1007/s11625-011-0149-x.

Mahmud, Bakhtiar. "Teacher Solution To Solve The Problem In Implementing The Activities Used In Teaching Speaking English In Islamic Boarding School Darussalam Gontor." In The 2nd TEYLIN International Conference Proceedings, 81-88, 2017.

Mas'udi, M Ali. "Peran Pesantren Dalam Pembentukan Karakter Bangsa." Paradigma 2, no. 1 (2015).

Monaco, Michele, dan Malissa Martin. "The Millennial student: A new generation of learners." Atbletic Training Education Journal 2, no. 2 (2007): 42-46.

Nur, Tajudin. "Sumbangan Bahasa Arab Terhadap Bahasa Indonesia Dalam Perspektif Pengembangan Bahasa dan Budaya." Humaniora 26, no. 2 (2014): 235-43.

Ostrom, Elinor. "A General Framework for Analyzing Sustainability of SocialEcological Systems.” Science 325, no. 5939 (2009): 419-422.

Pletka, Bob. Educating the Net Generation: How to Engage Students in the 21st Century. 2 ed. Santa Monica, CA: Santa Monica Press, 2007.

Republika.co.id. "Ratusan Naskah Kuno Cirebon Memprihatinkan." 
republika.co.id, 2012.

http://www.republika.co.id/berita/nasional/umum/12/03/25/m1 foraratusan-naskah-kuno-cirebon-memprihatinkan.

Roksa, Josipa, dan Richard Arum. Academically Adrift: Limited Learning on College Campuses. Chicago: University of Chicago Press, 2011.

Saepuloh, Rahdian. "Education 3.0." padepokanmargosari.com, 2016. https:/ / padepokanmargosari.com/2016/03/23/education-3-

$0 /$ ?iframe $=$ true\&theme_preview $=$ true.

Scholz, Roland W., Daniel J. Lang, Arnim Wiek, Alexander I. Walter, dan Michael Stauffacher. "Transdisciplinary case studies as a means of sustainability learning: Historical framework and theory." International Journal of Sustainability in Higher Education 7, no. 3 (2006): 226-51. https://doi.org/10.1108/14676370610677829.

Schwab, Klaus. The Fourth Industrial Revolution. Geneva, Switzerland: World Economic Forum, 2016.

Seemiller, Corey, dan Meghan Grace. Generation Z Goes to College. New York: Jossey-Bass, 2016.

Shoimin, Aris. Guru Berkarakter untuk Implementasi Pendidikan Karakter. Yogyakarta: Gava Media, 2014.

Subdirektorat Demografi. "Penduduk Indonesia: Hasil Survei Penduduk Antar Sensus 2015.” Katalog BPS 2101014. Jakarta, 2015.

Tjandrawinata, Raymond R. "Industri 4.0: Revolusi Industri Abad Ini Dan Pengaruhnya Pada Bidang Kesehatan Dan Bioteknologi." Dexa Laboratories of Biomolecular Sciences (DLBS) 29, no. February (2016): 1-12. https://doi.org/10.5281/zenodo.49404.

UNESCO. "Towards Knowledge Societies for Peace and Sustainable Development.” Paris, 2013.

Wekke, Ismail Suardi. "Arabic Language Teaching and Learning in Muslim Minority of West Papua.” Jurnal Pendidikan Islam 6, no. 1 (2017): 147-68. https://doi.org/10.14421/jpi.2017.61.147-168.

Zscheischler, Jana, Sebastian Rogga, dan Thomas Weith. "Experiences with transdisciplinary research: Sustainable land management third year status conference." Systems Research and Behavioral Science 31, no. 6 (2014): 751-56. https://doi.org/10.1002/sres.2274. 
250 | Arabiyatuna : Jurnal Bahasa Arab, Vol. 3, No. 2, 2019 